\title{
Work from Home Management and Work-Life Balance in the Midst of a Health Crisis, Impact on Life Domain and Work: An Exploratory Study on Cameroon
}

\author{
Dr BELINGA BESSALA Jacob Patrick \\ Teacher Researcher \\ Greg Laboratory: Economics and Management Research Group \\ LEMA Laboratory: Applied Economics and Management Laboratory \\ Associate Professor - Carlson School of Management - University of Minnesota \\ Faculty of Economics and Applied Management, University of Douala, P.O Box: 4032, \\ ORCID ID: 0000-0001-7236-0564 \\ bbjacob4ever@gmail.com
}

\begin{abstract}
In order to reduce the spread of the virus, the COVID-19 pandemic, which has rocked the world, has caused many workers to no longer come to their places of work. This has led employers and employees to seek alternative working methods, especially in a growing and emerging economy like Cameroon's. Due to the pandemic, most, if not all, workers have to work from home (WFH). As a result, WFH has become a political priority for most governments. In doing so, the terms and conditions must be worked out keeping in mind the practicality of both employers and employees. However, this current situation offers a unique insight into the efficiency of working from home and could play a critical role in future policies that reshape the current structure of working hours, perhaps allowing more flexibility. Using an exploratory framework and SWOT (Strength, Weakness, Opportunity, and Threat) analysis, this study examines the continuing experience of the employer and employees in Cameroon. A critical overview and related recommendations have been developed for future policy decisions. It will also critically examine whether this working arrangement will remain as a transitional element responding to exceptional circumstances, or whether it could be a permanent arrangement.
\end{abstract}

Keywords: work from home, work-life balance, covid-19, Cameroon, pandemic,.

DOI: $10.7176 / \mathrm{EJBM} / 13-16-03$

Publication date: August $31^{\text {st }} 2021$

\section{Introduction}

The new coronavirus (COVID-19), a worldwide pandemic, has challenged society in ways once thought to be unimaginable, forcing people to reconsider a wide variety of practices, from work to play, to going through basic travel and daily chores. Not only has this had individual impacts, but it has also had an impact on countries as a whole from an economic perspective, which has completely crippled a range of economic sectors. Although organizations were prepared mentally, the scope and solution remained unthinkable and still is a major challenge. Currently, the main known mode of transmission is through respiratory droplets, and is therefore considered to be spread through close contact with other people. Currently, the tools to fight against the viral spread are the correct use of masks, the introduction of social distancing measures and the practice of good hand hygiene according to the Ministry of Public Health of Cameroon (MINPH). It should also be noted that possible vaccines are also being implemented at the time of writing this article but are also the subject of much controversy. The World Health Organization (WHO) declared the COVID-19 outbreak a global health emergency on January 31, 2020 (WHO 2020). Since then, the virus has spread at super speed.

The virus has spread widely around the world, with more than 153 million confirmed cases and more than 3.2 million confirmed deaths as of May 3, 2021, and the number is steadily increasing (WHO 2021). As COVID19 continues to spread across the globe, some governments around the world have imposed more than once strict lockdowns with the closure of facilities as well as banning non-essential gatherings to protect hospitals from the risks of be overwhelmed by possibly infected people. Many of their counterparts urged their citizens to stay at home as much as possible and practice social distancing to limit face-to-face interactions with others. In addition, employers are advised to conduct a workplace risk assessment specific to Covid-19, taking into account each individual, in order to determine the safety of their employees working on site. Companies in the UK for example are required to openly share the results of the risk assessment with the human resource (HM Government 2020). This could be because works offices locations are among the top three places where the odds of being infected with COVID-19 are high, according to Dr Zhong Nanshan, a renowned expert on respiratory diseases (Hong Kong Economic Times Limited 2020). If the risk is too great, employers are forced to accept alternative working methods, by practicing social distancing at work or by implementing WFH.

Before the pandemic, discussions about the future of personal work dynamics were unclear and often 
questioned. COVID-19 has forced people to make a decision, and with the world having to adapt quickly, many companies have chosen to try WFH. WFH practices have been widely used, as it can be seen in the United States, where studies show that as of May 2020,35.2\% of the workforce was working from home, an increase from 8 , $2 \%$ in February. In addition, $71.7 \%$ of workers who telecommute have proven that they can work just as efficiently (Bick, Blandin and Mertens 2020). In Cameroon, directions for WFH have been given by governments, where government's employees who themselves WFH, while advisory opinions have been sent to employers of private organizations, as a precautionary measure to avoid further spread by reducing social contacts (Nsangou 2020). Before the pandemic, the idea of WFH in Cameroon was a fantasy for many people, but such a practice was considered impractical for densely populated cities like Douala or Yaoundé. This is mainly due to the fact that working from home requires a quiet and dedicated space to carry out professional tasks, which can be a real challenge for those who live in small houses where precariousness reigns.

Douala, for example, is well known for its tiny dwellings, in which the average living area per person was only 15 square meters in 2018 (Ministry of Housing and Housing 2018), or about 25\% less than Senegal and $60 \%$ less than the Republic of Congo (Ecofin 2020). Over the years, there has been a belief in all cities that workers must be physically present at the office to perform the job. Now that the pandemic has forced a trial of telecommuting across the country, for many it is the first time they have been working remotely and, to a large extent, it is proving to be a success. Therefore, there is a unique opportunity to assess the possibility of having WFH as one of the future work models for such a growing, emerging economy such as Cameroon. Being one of the first studies in this field, we aim to analyze three different dimensions. First, this study attempts to improve the understanding of WFH, including the factors that influence as well as the practicality and effectiveness of this working arrangement. Second, the scrutiny of the potential outcomes of WFH in the areas of work and workers' lives in general, such as flexibility and motivation at work.

Finally, our survey in the context of Cameroon adds distinctions to the record of Cameroon's response to the COVID-19 crisis, which is widely considered to be victorious due to strong "community capacity" or social mobilization (MINCOM speech 2020). The rest of this article has the following structure. The following section deals with the COVID-19 pandemic and WFH in Cameroon, with a particular attention arrangements during the pandemic. Then, in order to improve understanding of the concept of telework, this article will provide an overview. Subsequently, the framework of the study and a SWOT (Strengths, Weak, Opportunities, and Threats) analysis for the WFH survey are presented, followed by a discussion of its experience in Cameroon. The final section includes the conclusion, policy implications and recommendations.

\section{COVID-19 PANDEMIC AND WFH IN CAMEROON}

Many countries have adopted different means to deal with and defend themselves against the COVID-19 pandemic, and Cameroon is no exception. Cameroon was one of the first countries in Africa affected by the disease, the country announced its first confirmed case of COVID-19 on March 17, 2020 (Prime Minister, Head of Government's Speech). As of mid-May 2020, Cameroon is the Central African country most affected by the Covid-19 pandemic. The government has not implemented a full containment system across the country, but private employers and the public sector are recommended to use WFH to avoid physical contact. To support this provision, the Cameroonian Ministry of Telecommunications.

Since the start of the epidemic, the country has experienced two waves of infections, and the third wave currently underway is by far the most worrying at the time of writing. In response to the pandemic, Cameroon has taken an entirely different approach from that of its counterparts. The country has not imposed full lockdown, instead a series of measures have been implemented which include limited public gatherings, temporary suspended schools, special working arrangements, including WFH and remote work for civil servants and a call for private sector organizations to make similar arrangements where possible, among others. (Prime Minister, Head of Government 2020). In the very beginning, the country appeared to be able to contain the spread of the disease and keep its number of infections relatively low. Before the second wave of infections, there were a relatively lower number of infected cases and few deaths throughout the country (MINPH 2020). Things have gradually returned to normal, schools have reopened and restrictions on social distancing have been removed. The country was greeted and congratulated for its management of the crisis as a success with regard to the management of the spread of COVID-19 (MINCOM 2020 Speech, Government Spokesman). Some have recognized the government's rapid action against the COVID-19 crisis. However, in early July 2020, COVID-19 cases in Cameroon started to explode. The situation is deteriorated worryingly; stricter measures have been deployed to control the spread of the virus, such as the new rules on the compulsory wearing of the mask in all public places, etc. (MINPH 2020). However, some government regulations such as the suspension of catering, pleasures and food services have generated considerable controversy, especially from those who could not WFH due to the nature of their work, citing inconvenience and the lack of places to eat (Cameroon Tribune 2020). The government then backtracked and decided to resume catering services with a curfew from 6 p.m. (Prime Minister Head of Government). The infection finally started to drop at the end of August; certain barrier measures have 
been gradually relaxed. Unfortunately, the number of confirmed cases has increased again since mid-November 2020 , with 22,421 confirmed cases registered as of November 11, 2020, while the death rate has climbed to 523 (MINPH 2020).

Cameroon is struggling to cope with the third wave of infection at the time of writing.

Cameroon, like most commons countries, has long followed a standard practice for working in a formal office environment, where $90 \%$ of Yaoundé and Douala employees surveyed said they are required to work in the office during regular business hours office without flexible work options, offered, in an interregional survey on the global employment trend where the Cameroonian government planned to reach 120,000 teleworkers by 2018 (ILO 2020). We can see that even in developed countries, only a small proportion of people had the experience and the opportunities of WFH before the pandemic, the subject still remaining largely taboo in professional circles in Cameroon. However, the spread of the coronavirus has caused unexpected changes in people's lives in so many ways, which is leading people all over the world to WFH, and therefore Cameroon being no exception. At the onset of the pandemic, the first wave of infection in Cameroon, civil servants (excluding those providing emergency and essential public services) and state-funded academic staff were the first group of 'employees authorized to WFH, as a preventive measure to mitigate the spread of the virus. Some private companies, such as UBA (United Bank for Africa) and MTN Cameroon, among others, have also allowed their back office employees to join WFH (GICAM 2020).

Working after the post-epidemic period may be the time to pay attention to the work alternative that organizations are going to adopt. For example, Glothelo, a leading online platform based in Douala, seems to be the first company in the Littoral region to move definitively towards WFH (GICAM 2020). Even more surprisingly, a survey carried out during the second wave of the infection in Douala and Yaounde shows that most of the employees interviewed have experienced WFH for at least one day per week, and should continue WFH for at least one day per week at least one or two days a week after the pandemic (GICAM 2020). The country has the opportunity to experience a large part of its workforce WFH, which triggered a new round of debate on the pragmatic nature of such a working practice. Some have expressed concerns about employee productivity (Gorlick 2020), while others have advocated that WFH not only improves employee productivity (Baker, Avery and Crawford 2007), but also provides greater flexibility in working conditions and promotes a better WLB (work-life balance), (Dizaho, Salleh and Abdullah 2017). WFH which was originally initiated in Cameroon in response to the pandemic is in fact being absorbed smoothly thanks to the international standards of technology from which the population benefits.

Table 1. Timeline of homework during COVID-19 in Cameroon

\begin{tabular}{|c|c|c|}
\hline WAVE 1 & WAVE 2 & WAVE 3 \\
\hline $\begin{array}{l}\text { 01/28/2020: The government has put in } \\
\text { place special working arrangements for } \\
\text { civil servants and called on private sector } \\
\text { organizations to make similar } \\
\text { arrangements where possible. }\end{array}$ & $\begin{array}{l}\mathbf{0 3 / 2 1 / 2 0 2 0 :} \text { The government } \\
\text { has again established special } \\
\text { working arrangements for } \\
\text { government departments }\end{array}$ & $\begin{array}{l}\text { 07/13/2020: The government had } \\
\text { no plan to allow civil servants to } \\
\text { switch to teleworking so private } \\
\text { sector managers took the lead and } \\
\text { implemented telework modalities. }\end{array}$ \\
\hline $\begin{array}{l}\text { 03/01/2020: About } 20 \text { unions, such as the } \\
\text { Confederation of Trade Unions of } \\
\text { Cameroonian Workers, GICAM, have } \\
\text { urged the government to put in place } \\
\text { practical telework arrangements until } \\
\text { COVID-19 is under control. }\end{array}$ & $\begin{array}{l}\text { 29/03/2020: } \\
\text { Confederation Union of } \\
\text { workers of Cameroon } \\
\text { questioned the working } \\
\text { arrangements concerning the } \\
\text { ministries and found that } \\
\text { they were not strictly } \\
\text { enforced. }\end{array}$ & $\begin{array}{l}\text { 07/16/2020: Dr TOBY Roselyne } \\
\text { Tanga, expert in infectious } \\
\text { diseases, urged the government to } \\
\text { implement teleworking measures. } \\
\text { 07/20/2020: The government has } \\
\text { put in place a special working } \\
\text { regime for ministries. }\end{array}$ \\
\hline $\begin{array}{l}\text { 02/03/2020: The officials have resumed } \\
\text { service. }\end{array}$ & $\begin{array}{l}\text { 04/05/2020: The officials } \\
\text { have returned to their posts. }\end{array}$ & $\begin{array}{l}\mathbf{0 8 / 2 4 / 2 0 2 0 :} \text { Civil servants have } \\
\text { gradually returned to their } \\
\text { positions. } \\
\text { 12/18/2020: HSBC said it would } \\
\text { allow its employees to work up to } \\
\text { four days a week from home. }\end{array}$ \\
\hline
\end{tabular}




\begin{tabular}{|c|c|c|}
\hline $\begin{array}{l}\text { 05/03/2020: A survey carried out by the } \\
\text { Union of Employees of Social Protection } \\
\text { Organizations found that the majority of } \\
\text { respondents. (over } 90 \% \text { ) disagreed or } \\
\text { strongly disagreed with the cancellation of } \\
\text { teleworking arrangements in the } \\
\text { organizations they work with. }\end{array}$ & $\begin{array}{l}\text { 06/09/2020: The Cameroon } \\
\text { Inter-Employer Group, } \\
\text { based in Douala, has } \\
\text { announced a permanent } \\
\text { transition to teleworking. }\end{array}$ & $\begin{array}{l}\text { 20/01/2021: The government } \\
\text { reminded the various ministries and } \\
\text { their regional delegations to } \\
\text { consider adopting flexible working } \\
\text { arrangements on the assumption } \\
\text { that the provision of public services } \\
\text { would be maintained. } \\
\mathbf{0 2 / 0 3 / 2 0 2 1 : ~ T h e ~ g o v e r n m e n t ~ t o ~} \\
\text { adopt special measures for regional } \\
\text { government institutions so that the } \\
\text { public service is maintained }\end{array}$ \\
\hline $\begin{array}{l}\text { 01/28/2020: The } 08 \text { State Universities as } \\
\text { well as several private organizations such } \\
\text { as: UBA, Orange Cameroon, MTN } \\
\text { Cameroon, AXA have set up teleworking } \\
\text { arrangements according to the instructions } \\
\text { of the government }\end{array}$ & $\begin{array}{l}\text { 03/21/2020: The association } \\
\text { of media men in Cameroon } \\
\text { has also strongly urged } \\
\text { organizations to implement } \\
\text { telework in order to reduce }\end{array}$ & $\begin{array}{l}\text { 07/13/2020: This has generated } \\
\text { lively controversy on the side } \\
\text { public opinion. }\end{array}$ \\
\hline
\end{tabular}
Source: Authors

\section{WORKING AT HOME: AN OVERVIEW}

WFH is currently known as an alternative method at minimizing the risk of COVID-19 infection. However, this is not a new concept and has been brought to the attention of several schools of thought for many years. The concept of WFH was first mentioned by Nilles (1988) since 1973. WFH has been defined in different terms over the four decades, namely remote work, flexible workplace, work from distance, online work (e-working). These terms refer to the ability of employees to work in flexible workplaces, especially at home, using technology to perform tasks (Gajendran and Harrison 2007; Grant et al. 2019).

A recent study by Dingel and Neiman (2020) found that $37 \%$ of work could be done from home during the COVID-19 pandemic in the United States, such as financial work, business management, professional and scientific services. Some jobs, especially those related to healthcare, agriculture and health care cannot be done from home. Although the acceptance of WFH has increased around the world, academic communities across the world are discussing its pros and cons.

WFH has beneficial effects for both employers and employees. Benefits include and are not limited to reduce commute time, avoiding office policies, using less office space, increasing motivation, improving gender diversity (e.g. women and men careers), healthier workforce with less absenteeism and turnover, better retention of satisfaction and better productivity (Mello 2007; Robertson, Maynard and McDevitt 2003). Studies have indicated evidence of these benefits; for example, research in the Greater Dublin area by Caulfield (2015) found that employees save travel time for instance. Some studies point out that WFH can reduce turnover and increase employee productivity, work engagement and job performance (Collins and Moschler 2009; Delanoeije and Verbruggen 2020). Likewise, e-working can increase productivity, flexibility, job satisfaction, WLB (Work-Life Balance), in particular by reducing conflicts between work, private life and travel (Grant et al. 2019).

In addition, Purwanto et al. (2020) argued that WFH could support employees in terms of time flexibility to achieve theirs tasks and save money to get to office. Conversely, the disadvantages of WFH include confusion or a blurred line between work and family, distractions, social isolation, with employees bearing the costs associated with WFH. According to Purwanto et al. (2020), WFH has some drawbacks, such as employees working from home who have to pay electricity and internet costs themselves. Collins and Moschler (2009) found that workers were isolated from their colleagues and that managers worried about reduced productivity when working from home. In addition, the relationship between colleagues could also be affected (Gajendran and Harrison 2007). Employees may be distracted by the presence of young children or family members when they work from home (Baruch 2000; Kazekami 2020) and the blurred lines between work and family life lead to overwork (Grant et al. 2019). Similarly, the management of the work-family boundaries of remote workers studied by Eddleston and Mulki (2017) found that WFH is linked to the inability of remote workers to disengage from work. .

Studies have shown that WLB (Work-Life Balance) can be improved by working from home. Likewise, Grant et al. (2013) stated that working online (e-working) would improve WLB, and teleworkers found that it was possible to combine work-life and non-professional life. Online workers have found that their productivity is improved by working online (Grant et al. 2019). Bloom et al. (2015) found that job satisfaction increased when working from home. WFH is also positively associated with satisfaction with family life (Arntz, Sarra and Berlingieri 2019; Virick, DaSilva and Arrington 2010). Kazekami (2020) studied worker productivity in Japan and found that WFH increases life satisfaction. Moreover, working people have to spend less time commuting to 
work and therefore have more time to spend with their families. (Uddin 2021)

WFH has become a political priority for most governments to deal with the Covid-19 pandemic. In doing so, policies must be designed with practicality in mind for both employers and employees, as there will be consequences for both groups in one way or another.

\section{WORKING FROM HOME : A SURVEY FRAMEWORK}

The framework for this study has been developed based on an examination of WFH, teleworking, e-working, remote working, and other flexible working environment. The framework is thus drawn to guide the investigation into WFH during the COVID-19 pandemic in Cameroon, in order to examine whether this working arrangement will remain as a transitional element responding to exceptional circumstances, or if it could be an element of permanent arrangement. Firstly, in the proposed framework, two organizational factors and the individual-family are linked to WFH. We aim to examine how these factors have influenced WFH. Secondly, in order to explore the impacts of WFH on the areas of work and personal life, it is linked to the respective outcomes on the areas of work and life which are embodied in specific aspects. More detailed descriptions of the elements of the framework, as shown in Figure 1, are described in the next section.

There are two main factors that will be taken into consideration by workers when WFH or remote working. "Organizational factors" would initially be involved in the work of employees. Studies have shown that organizational factors are crucial for the modalities of WFH arrangements (e.g. Baker, Avery and Crawford 2007; Grant et al. 2019).

Figure 1: Analytical framework.

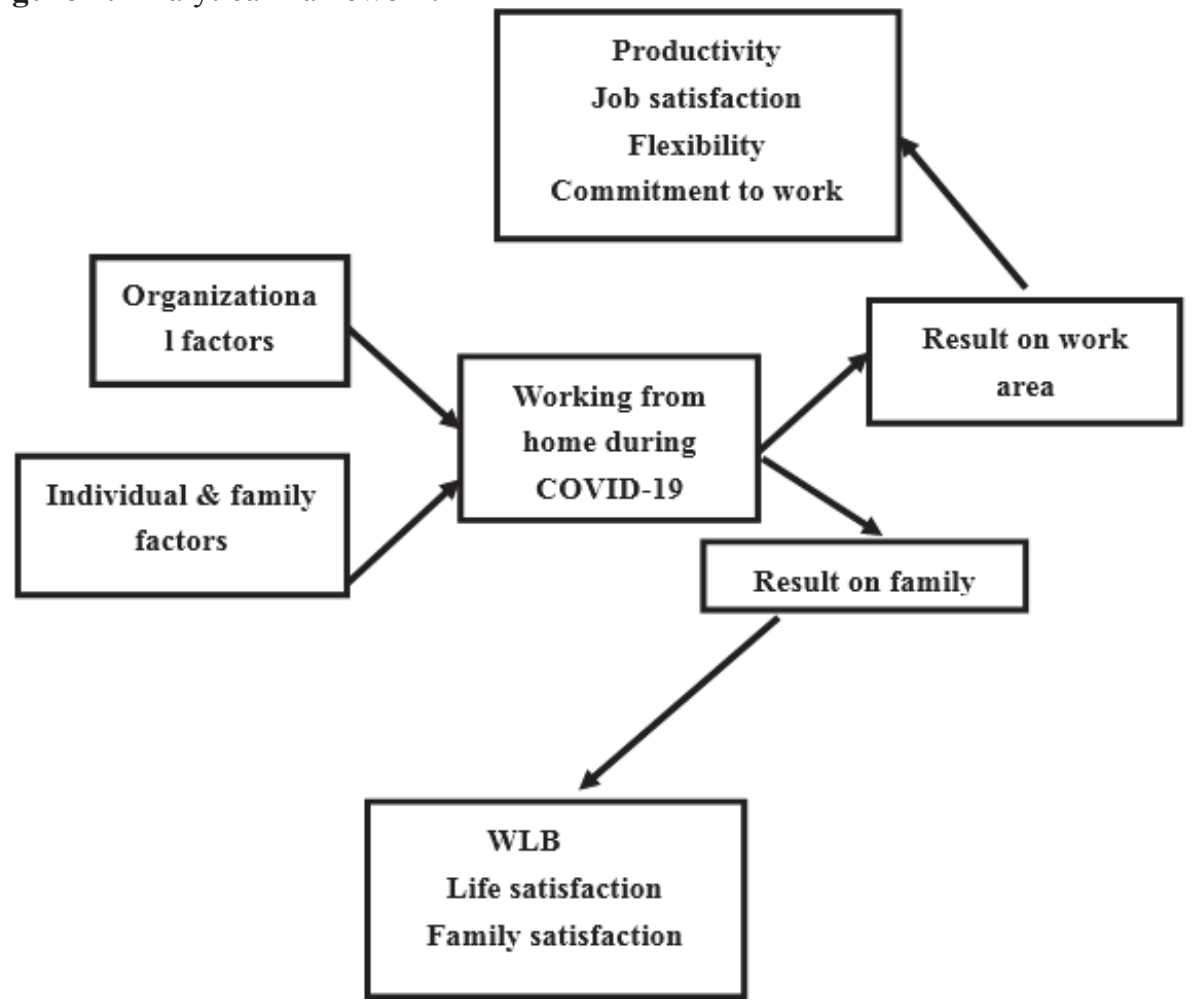

Sources: Authors

Examples include, but not limited to, employers who are sympathetic to requests from their employees who would like to WFH, bearing the costs of WFH facilities, training in the use of technology, as well as organizational communication. . Other supports for WFH arrangements include employee welfare and organizational IT support, etc. (Baker, Avery and Crawford 2007). Organizational confidence and the confidence of managers are other organizational factors. As previous research shows, organizational confidence and managerial confidence are correlated with outcomes of WFH. Studies by Baruch (2000), Grant et al. (2019) and Baker, Avery and Crawford (2007) found that a culture of trust in an organization, as well as the trust of colleagues and managers is necessary for WFH and working online (e-working). Based on previous studies, these factors were found to be strongly correlated with WFH.

As noted in previous studies, WFH is influenced not only by organizational factors, but also by "individual and family factors" (Baker, Avery and Crawford 2007; Solıs 2016). Baruch (2000) suggested some factors that should be taken into account for WFH, such as self-discipline, self-motivation, the ability to work independently, tenacity, self-organization, self-confidence in itself, skills in time management, good computer and technological 
knowledge" (43-44). A study found that the number of working days and the time a person spends teleworking also has an impact on work-family conflict (Solis 2016). In addition to individual factors, family factors also have an influence on teleworking / working from home. For example, household characteristics such as the size of the living space, the number of family members sharing the same space as well as the number and age of children in the household are considered to be family factors influencing WFH (Baker, Avery and Crawford 2007). In addition, WFH can also be influenced by the individual workspace available in the home and the number of people present when working from home (Baruch 2000; Shaw, Andrey and Johnson 2003). The outcome of WFH can be viewed in two domains which are the outcomes on the "domain of work" and the "domain of life". Research studies reveal that WFH has positive outcomes in the field of work, i.e. productivity, job satisfaction, flexibility and engagement at work.

Productivity has been improved through the adoption of WFH or working from distance, e-working and remote working, especially when it comes to creative tasks (Dutcher 2012; Grant, Wallace and Spurgeon 2013). Teleworking or working from home is also believed to increase job satisfaction, and studies have shown that the relationship between telework and job satisfaction is interdependent (Troup and Rose 2012; Bae and Kim 2016; Smith, Patmos and Pitts 2018). WFH also has an impact on flexibility and engagement at work, as it allows workers to have more flexible time to complete their work and does not require them to follow office hours (Grant et al. 2019; Purwanto et al. 2020). WFH also has a positive effect on the professional engagement of employees (Gerards, de Grip and Baudewijns 2018; Sardeshmukh, Sharma and Golden 2012). However, it has also been argued that WFH has an inverse outcome on the work domain, which is negatively associated with motivation at work, for example, WFH can cause employees to lose professional motivation if they have to endure the hardships WFH costs (Purwanto et al. 2020).

Studies have indicated that WFH has both negative and positive outcomes in the area of life. The area of life might include WLB (Work-Life Balance), life satisfaction, and family satisfaction. WLB can refer to workfamily interference, work-family balance, family satisfaction, and life satisfaction (Gregory and Milner 2009; Kalliath and Brough 2008). Some studies have found that WFH has negative effects on the area of life. For example, Grant et al. (2019) found that online workers struggle to manage the boundaries between working time and free time, resulting in a tendency for work overload. Others have discovered that there were blurred lines between work and family life (Grant et al. 2013) and can lead to overwork and then affect WLB. Nevertheless, several studies have shown that WFH or distance working is positively associated with family and life satisfaction (Eddleston and Mulki 2017; Virick, DaSilva and Arrington 2010). Arntz et al. (2019) found that WFH tends to increase life satisfaction for male workers without children. Additionally, WLB has also been found to be positively associated with life and family satisfaction (Chan et al. 2016; Noda 2020). Exploitation of the exploratory framework combined with a SWOT analysis will help to investigate the current experience of employers and employees and to better understand the real situation of teleworking or working from home in Cameroon.

\section{SWOT ANALYSIS (STRENGTHS, WEAKNESS, OPPORTUNITY, THREAT)}

The SWOT Matrix (Strengths, Weaknesses, Opportunities, and Threats) is a matrix or method of analysis. It makes possible to determine the options offered in a strategic area of activity. In business, it often use to determine through the four modalities of the matrix what is the position of a business in a market segment compared to its competitors in order for the latter to improve or review its position in the segment concerned. Similarly in the case of our study we will use it to highlight the place occupied by WFH in Cameroon and at the end suggests some recommendations accordingly in relation to the place and effectiveness of WFH currently in Cameroon.

It is essential to identify the potentials as well as the limitations of WFH using a SWOT analysis which could help to examine the WFH situation in Cameroon. The analysis of the Strengths, Weaknesses, Opportunities and Threats of WFH, with particular emphasis on Cameroon, was carried out, as explicitly shown by table 2 . 
Table 2: SWOT matrix.

\begin{tabular}{|c|c|c|}
\hline \multicolumn{3}{|c|}{ SWOT analysis of the situation in Cameroon } \\
\hline & Work from the office & Telework / WFHW \\
\hline Strength & $\begin{array}{ll}- & \text { Face-to-face networking / interaction } \\
\text { - } & \text { opportunities } \\
\text { - } & \text { Pollaboration Opportunities } \\
& \text { supervision problems } \\
- & \text { Separation of work and personal life } \\
- & \text { A greater sense of belonging } \\
- & \text { Better integration for new employees } \\
- & \text { An environment conducive to } \\
- & \text { concentration } \\
- & \text { Better access to technology } \\
\text { No risk of information leakage }\end{array}$ & $\begin{array}{ll}- & \text { Flexible arrangement } \\
\text { - } & \text { No distractions in the office (for } \\
\text { - } & \text { example, no office noise) } \\
\text { - } & \text { Comfonomy / freedom } \\
& \text { environment / familiar } \\
\text { - } & \text { Save time / no trip } \\
- & \text { Save money (e.g. spend less on } \\
& \text { renting office space) } \\
- & \text { Work Life Balance } \\
- & \text { Reduce absenteeism }\end{array}$ \\
\hline Weaknesses & $\begin{array}{ll}\text { - } & \text { Lack of flexibility } \\
\text { - } & \text { Sedentary lifestyle } \\
\text { - } & \text { Workplace conflicts (for example, } \\
& \text { office politics) } \\
\text { - } & \text { Noisy workplace (for example, loud } \\
& \text { conversations) } \\
\text { - } & \text { Time wasted in unnecessary meetings } \\
\text { - } & \text { Travelling expenses } \\
\text { - } & \text { Higher operating costs (e.g. utility } \\
\text { bills) }\end{array}$ & $\begin{array}{ll}- & \text { Entertainment (family members, } \\
\text { household chores) } \\
\text { - } & \text { Uncomfortable environment (for } \\
\text { example, living in a small place) } \\
\text { - } & \text { Lack of supervision } \\
- & \text { Communication barriers } \\
- & \text { Missing social interaction / } \\
& \text { loneliness } \\
- & \text { Lack of hardware support } \\
- & \text { Blurred lines between work and } \\
\text { - } & \text { Unersonal life } \\
& \text { lying on a sofa all day) }\end{array}$ \\
\hline Opportunities & $\begin{array}{l}\text { - } \begin{array}{l}\text { Maintain a professional appearance } \\
\text { (build lasting relationships with } \\
\text { clients) }\end{array} \\
\end{array}$ & $\begin{array}{ll}- & \text { Hybrid models } \\
- & \text { New talents from all over the } \\
& \text { world }\end{array}$ \\
\hline Threats & $\begin{array}{l}\text { - } \quad \text { Less diversity in the workforce (e.g. } \\
\text { married women and the elderly) } \\
\text { - }\end{array}$ & $\begin{array}{cl}\text { - } & \text { Cyber security (data theft) } \\
-\quad & \text { Confidentiality (Loss of company } \\
\text { - } & \text { No WFloyee / customer data) } \\
-\quad \text { Additional expenses associated } \\
\text { with working from home } \\
\text { High competition (job can be outsourced } \\
\text { to cheap foreign labor) }\end{array}$ \\
\hline
\end{tabular}

Sources: Authors

\section{DISCUSSION}

COVID-19 has given the world the chance to experience WFH, which has long been a work option desired by many, especially in a place like Cameroon where family labor is a double benefit even more exploited. The responsibility of elderly parents and / or young children coupled with a demanding work environment has been a challenge that calls into question the WLB (Work-Life Balance) of the workforce in Cameroon.

Based on preliminary studies of the reactions obtained from both employers and employees to teleworking or working from home in Cameroon, it appears that the first reactions to the change in work format have been favorable. However, beyond this superficial satisfaction, there are many shortcomings in the current structure of WFH in Cameroon and as a result; there is more dissatisfaction with the lack of practical policies to ensure an efficient and effective implementation of WFH. .

At the same time, in measuring the efficiency of WFH practices, the opinion of the people concerned, in the case of teleworkers, is essential to take into account. Looking at the opinions received at the start of the practice, an overwhelming majority of opinions were positive.

A study conducted in December 2020 showed that more than $80 \%$ of workers preferred at least partial WFH measures in place, with figures varying depending on the number of days per week, suggesting a preference for a mixed working mode. The most common reasons for this, shown, were more time to rest ( $68.5 \%$ strongly agree), a decrease in work-related stress $(73.7 \%$ strongly agree) and an improvement in life. WLB (65.4\% strongly 
agree). Opinions also showed that employers were supportive, with $48 \%$ of those who responded being of the opinion that employers provide adequate support to implement an effective WFH strategy (GICAM, 2020). However, although this is the most popular opinion, it does not express the majority opinion, suggesting that even in the early days there was room for improvement. This can be seen in the same study, with the majority of respondents agreeing on all of the challenges discussed, including lack of materials, family disruption, and poor communication with co-workers. Another study highlighted the health benefits of WFH, with over $70 \%$ of workers feeling mentally relaxed when working from home. This study also shed light on workers who favor and support WFH measures (68\%), flexible hours (78\%) and compressed working hours (69\%) (GICAM 2020). Despite the general preference of Cameroonian workers for WFH practices, it is clear that there are glaring issues that need to be addressed. A study highlights dissatisfaction with internal infrastructure, such as limited or no access to resources such as office documents (IPEC 2020). This might suggest a poor level of preparation for this situation, but since this is a new work practice, the level of preparation is limited for both employers and employees. This has resulted in inconsistent or delayed performance on the part of employees and a lack of flexibility and tolerance on the part of employers. It can be argued that employers may have made efforts, but there was a lack of consistency, with only $30 \%$ of employers investing in new forms of communication technology, and even less in other areas (ILO Report 2020). Another study suggests that Cameroon's unique work situation makes WFH less favorable for workers, with workers failing to distinguish between personal and professional spaces. The survey reveals that "employees with more than 30 years old had to juggle domestic and professional commitments simultaneously", citing a possible reason for this additional difficulty being that populations in Cameroon tend to live in multigenerational households, which also leads to less space compared to their western counterparts, thus creating many distractions and an imbalance between work and home life. In addition, the same study finds that $65 \%$ of workers missed going to the office and missed the human interaction, work environment and face-to-face interaction for better collaboration (ILO 2020).

Another proof is that a good part of the civil servants in Cameroon especially in the city of Yaoundé and Douala were authorized to WFH during the pandemic, various regional delegations provided IT support such as newly installed computers, mobile devices or other equipment, software as well as improved communication, network or database capabilities for their staff in order to remote working effectively. Similar to the studies by Baker, Avery and Crawford (2007) and Grant et al. (2019), it is revealed that organizational factors such as organizational support influence WFH. However, there are many confidential documents that officials can only access through intranets and government servers through virtual private networks (VPNs) for email delivery as well as information storage and retrieval when they are working from distance (Ministry of Communication, Government spokesperson 2020).

Additionally, as Baker, Avery and Crawford (2007) have pointed out, WFH can be affected by individual and family factors. Some Cameroonian officials have young children and while teleworking / working from home have had to look after their children (IPEC 2020). While there is some assistance from organizations that have adopted WFH. However, it remains true that workers may experience difficulty in accessing organizational information, which can be inconvenient.

While the special work regime has allowed people to WFH to mitigate the spread of the Covid-19 in Cameroon, the current WFH procedure lacks clear guidelines. For example, there has been controversy and confusion over whether adverse weather conditions would force workers to work from home or would they be eligible for time off as it is the case in the traditional working regime (Cameron Tribune 2020). Clear guidelines or explicit direction are therefore essential.

Besides Cameroon, other countries and around the world have adopted this new and now normal way of working. It has also affected workers, both at work and in the personal sphere. In Singapore, WFH is seen to increase worker stress even more, as proved in a study that found homeworkers to be more stressed than frontline workers from COVID-19 (Teo, 2020). Under other skies such as in India, WFH has caused $67 \%$ of people to suffer from sleep deprivation, especially during the period of confinement and in the absence of housekeepers to help them with housework. Which led them to do all the household chores at the same time as their work (Times of India 2020) Employees who worked from home in cities like Hong Kong, or countries like Singapore and India, were found to experience more stress, fear of job security, feeling anxious, lonely, exhausted. As shown in a survey conducted between May and July 2020 by the Hong Kong Mental Health Association, 87\% of those surveyed had symptoms of stress (Ng 2020b; Tam 2020). WFH in the COVID-19 era seems to have many negative consequences on this side of the globe on the area of workers' lives. (Uddin 2021) in her findings highlighted that highlights the significance of family support and a husband's cooperation in working women's quality of life during COVID-19 and beyond. Besides, co-workers, supervisors, organizational support, and workplace environment have also influenced WLB during the pandemic situation. This is critical because during COVID-19 domestic workers' aid has not been available. Nonetheless, throughout the pandemic, WFH has reshaped the traditional way of working into a promising future potential for work. 


\section{CONCLUSION}

Our research clearly shows that the once desired and highly favorable WFH has not proven to be one of the best options for the majority of the workforce in Cameroon. Interest in WFH remains anyway, but not in its current form. Better government guidelines and policies should be in place to properly regulate and make WFH feasible. An area where planning and implementation are an absolute necessity as well as guidance to adapt to remote online work. The decision to suspend face-to-face meetings and work in the traditional way was implemented quickly, but without any practical support and guidance on how to proceed. Workers are unaware of what WFH entails and lack the necessary resources for this change, such as software, access to official documents and a suitable workspace. Training workshops are needed if this practice is to be a feasible option or the new standard. The work life balance may be visible after the pandemic when WFH is no longer a forced mandate, but rather a flexible option. Our study in the future could analyze the status of WFH. Will it evolve or regress? In a postpandemic context, what place will the Cameroonian government and organizations give to WFH in a situation where they will no longer be obliged to do so because of the pandemic restrictions but rather by choice and a desire to adopt WFH as a regular way of working.

\section{RECOMMENDATIONS}

The recommendations below include a series of possible actions the Cameroonian government could take to make WFH more feasible in a local context.

1. In the short term, the Government should consider:

- Establish an official guide to the practical arrangements and methods of remote working for employees and employers;

- Taking into account the risk assessment related to COVID-19 when developing the official guide;

- $\quad$ Give different guidelines to different sectors;

- $\quad$ Take into account employee expectations in guidelines;

- Specification of minimum technological training requirements for the virtual office; and for technical teleworking installations.

2. In the long term, the Government should consider:

- $\quad$ Review of the possibility of working remotely to become the new standard;

- Review current labor laws and ensure that labor insurance policies are extended to work from home;

- $\quad$ Encourage small and medium-sized enterprises to adopt WFH measures by granting them subsidies and other incentives;

- Promote training and capacity building workshops as well as further promote favorable employment practices in the family environment.

\section{REFERENCES}

Arntz, M., BY Sarra, and F. Berlingieri. (2019) "Homework: Heterogeneous Effects on Hours Worked and Wages.” ZEW-Center for European Economic Research Discussion Paper No. Mannheim, Germany, 19015. Recovered from10.2139 / ssrn.3383408.

Bae, KB, and D. Kim. (2016). "The Impact of Decoupling from Teleworking on Job Satisfaction in US Federal Agencies: Does Gender Matter?" The American Review of Public Administration 46 (3): 356-371. doi: 10.1177 / 0275074016637183.

Baker, E., GC Avery, and J. Crawford. (2007). "Perceived satisfaction and productivity when professionals work from home." Human Resource Management Research and Practice 15 (1): 37-62.

Baruch, Y. (2000).Teleworking: advantages and pitfalls perceived by professionals and managers. New technologies, work and employment, 15 (1), 34-49. doi:10.1111/ 1468-005x.00063

Bick, A., A. Blandin and K. Mertens. (2020)."Working from Home After the COVID-19 Outbreak." CEPR Working Paper No. DP15000. Recovered fromhttps://ssrn.com/abstract= 3650114

Bloom, N., J. Liang, J. Roberts, and ZJ Ying. (2015). "Does working from home work? Evidence from a Chinese experience." The Quarterly Journal of Economics 130 (1): 165-218. doi:10.1093 / qje / qju032.

Cameroon Tribune Number 12342/8541 Top of the form Edition of 0605202118 (5) 8-10

Caulfield, B. (2015). "Does Working From Home Pay? A Review of Factors Influencing Home Working in the Greater Dublin Area." Transport Policy Case Studies 3 (2): 206-214. Doi:10.1016 / j.cstp.2015.04.004.

Health protection center. 2020a. Frequently Asked Questions About Coronavirus Disease 2019 (COVID-19). Accessed June 9.https://www.chp.gov.hk/en/features/102624.html\#F

Health protection center. 2020b. Latest status of COVID-19 cases (as of August 9, 2020). Accessed August 9.https://www.chp.gov.hk/files/pdf/local_situation_covid19 en.pdf

Health protection center. 2020c. Latest situation of COVID-19 cases (as of August 19, 2020). Accessed August 19.https://www.chp.gov.hk/files/pdf/local_situation_covid19_en.pdfChan, S. (2020). 9gag announces working from home forever. Accessed May 25.https: // www.humanresourcesonline.net/9gag-announces- 
work-from-home-forever

Chan, XW, T. Kalliath, P. Brough, O.-L. Siu, MP O'Driscoll and C. Timms. (2016). "Work-Enrichment and family satisfaction: the mediating role of self-efficacy and Work-Life Balance." The International Journal of Human Resource Management 27 (15): 1755-1776. Doi: 10.1080 / 09585192.2015.1075574.

Collins, JH and JJ Moschler. (2009). "The advantages and limitations of telecommuting." Defense AR Journal 16 (1): 55-66.

Delanoeije, J. and M. Verbruggen. (2020). "Inter-personal and intra-personal effects of teleworking: a quasi-field experience." European Journal of Work and Organizational Psychology 29 (6): 795-808. Doi: 10.1080 / $1359432 X .2020 .1774557$.

Dingel, JI and B. Neiman. (2020). "How much work can you do at home?" Journal of Public Economics 189: 104235. doi:10.1016 / j.jpubeco.2020.104235

Dizaho, EK, Salleh, R. and Abdullah, A. (2017). "Achieving work-life balance through flexible working hours and arrangements." Global Business \& Management Research 9 (1s): 455-465.

Dutcher, EG (2012). "The Effects of Telecommuting on Productivity: An Experimental Review. The Role of Boring and Creative Tasks." Journal of Economic Behavior \& Organization 84 (1): 355-363. Doi: $10.1016 /$ j.jebo.2012.04.009.

Ecofin (2020). The challenge of affordable housing in Africa, on the eve of a record population growth. Accessed January 6, 2020https://www.agenceecofin.com/gestion-publique/0601-72461-le-defi-dulogement-abrables-en-afrique-a-la-veille-d-un-record-de-croissance-demographique

Eddleston, KA and J. Mulki. (2017). "Towards Understanding Remote Workers' Work Management-Family Boundaries: The Complexity of Workplace Integration." Group management and organization 42 (3): 346387. doi:10.1177 / 1059601115619548.

Gajendran, RS and DA Harrison. (2007). "The good, the bad and the unknown about teleworking: a metaanalysis of psychological mediators and individual consequences." The Journal of Applied Psychology 92 (6): 1524-1541. doi:10.1037 / 0021-9010.92.6.1524. Gicam report (2020) Managing Workplaces in COVID-19: An Employer's Guide 5 (2) 11-13 Gerards, R., A. de Grip and C. Baudewijns. (2018). "Do new working methods increase engagement at work?" Staff Review 47 (2): 517-534. " ○ doi: 10.1108 / PR-022017-0050.

Gorlick, A. (2020). "Home Work Productivity Pitfalls in the Age of COVID-19." Stanford News. Accessed June 17, 2020.https://news.stanford.edu/2020/03/30/productivity-traps-work-at-home-age-covid-19 /

Grant, C., Wallace, L. and Spurgeon, P. (2013). An exploration of the psychological factors affecting the remote electronic worker work efficiency, well-being and work-life balance. Employee Relations, 35, 527-546. doi:10.1108 / ER-08-2012-0059

Grant, CA, LM Wallace, PC Spurgeon, C. Tramontano, and M. Charalampous. (2019). "Construction and initial validation of the e-Work lifecycle to measure online and remote work." Labor Relations 41 (1): 16-33. doi:10.1108 / ER-09-2017-0229

Gregory, A. and S. Milner. (2009). "Editorial: Work-Life Balance: A Matter of Choice?" Gender, work and organization 16 (1): 1-13.http://usir.salford.ac.uk/id/eprint/1737/. Doi: 10.1111 / d. 14680432.2008.00429.x.

Government HM. (2020). "Working Safely During COVID-19 in Offices and Contact Centers."https://assets.publishing.service.gov.uk/media/5eb97e7686650c278d4496ea/working-safelypendant-covid-19-offices-contact-centers-041120.pdf

JLL (2020). "Home and Beyond: What's New in the Hybrid Workplace?" Accessed July (2020).https://www.jll.com.hk/content/dam/jll-com/documents/pdf/research/apac/ap/jll-research-home-andaway-Jul-2020-last.pdf

Kalliath, T. and P. Brough. (2008). "Work-Life Balance: A Review of the Meaning of Building Balance." Journal of Management \& Organization 14 (3): 323-327. doi:10.5172 / jmo.837.14.3.323.

Kazekami, S. (2020). "Mechanisms for Improving Labor Productivity by Teleworking." Telecommunications Policy 44 (2): 101868. doi:10.1016 / j.telpol.2019.101868.

Mahi Uddin (2021). "Addressing work-life balance challenges of working women during COVID-19 in Bangladesh" Community, Work \& Family. https://doi.org/10.1111/issj.12267

Mello, JA (2007). "Effectively manage teleworking programs." Employee Rights and Responsibilities Journal 19 (4): 247-261. doi:10.1007 / s10672-007-9051-1.

Messenger, JC and L. Gschwind. (2016). "Three generations of teleworking: new ICTs and the (r) evolution from the home office to the virtual office." New Technologies, Work and Employment 31 (3): 195-208. doi:10.1111/ ntwe.12073.

Nilles, JM (1988). "Reducing Traffic through work from home A State Review and Selected Bibliography." Transportation Research Part A: General 22 (4): 301-317. doi:10.1016 / 0191-2607 (88) 90008-8.

Noda, H. (2020). "Work-Life Balance and Life Satisfaction in OECD Countries: A Cross-Sectional Analysis." 
Journal of Happiness Studies 21 (4): 1325-1348. Doi: 10.1007 / s10902-019-00131-9.

Nsangou A. 2020. Teleworking: Difficult accommodation. Cameroon tribune, April 7. Available athttps:/www.cameroon-tribune.cm/article.html/31623/fr.html/teletravail-difficile-accommodation

Planning Department. (2002). "Working Paper No. 23 A Study of the Implications of Information Technology on Planning." July 2020.https://www.pland.gov.hk/pland en/p_study/comp_s/ hk2030 / eng / wpapers / pdf / workingPaper_23.pdf

Purwanto, A., M. Asbari, M. Fahlevi, A. Mufid, E. Agistiawati, Y. Cahyono, and P. Suryani. (2020). "Impact of Telecommuting on Indonesian Teachers' Performance during the COVID-19 Pandemic: An Exploratory Study." International Journal of Advanced Science and Technology 29 (5): 6235-6244.

Robertson, MM, WS Maynard, and JR McDevitt. (2003). "Telecommuting: Managing Worker Safety in Home Office Environments." Professional security 48 (4): 30-36.

Sardeshmukh, SR, D. Sharma, and TD Golden. (2012). "Impact of telework on burnout and professional engagement: a model of job demands and professional resources." New Technologies, Work and Employment 27 (3): 193-207. doi:10.1111 / j.1468-005X.2012.00284.x.

Shaw, SM, J. Andrey, and LC Johnson. (2003). "The struggle for the balance of life: work, family and leisure in the lives of women teleworkers." World Leisure Journal 45 (4): 15-29. doi:10.1080 / 04419057.2003.9674333.

Smith, SA, A. Patmos, and MJ Pitts. (2018). "Communication and Telework: Study of Communication Channel Satisfaction, Personality and Job Satisfaction of Telework Employees." International Journal of Business Communication 55 (1): 44-68. doi:10.1177 / 2329488415589101.

Solıs, MS (2016). Telework: conditions that have a positive and negative impact on work-family conflict. Academia Revista Latinoamericana de Administracion, 29 (4), 435-449.

Sun Life (2020). Accessed May 20. Health-conscious office workers appreciate the benefits of working from home. Recovered fromhttps://www.sunlife.com.hk/en/about-us/newsroom/ press releases / $2020 /$ health conscious office workers /

Tam, L. (2020). Accessed August 17. Mental health and working from home: what businesses can do to help staff amid a protracted Covid-19 disruption? Recovered fromhttps: //www.scmp. com / lifestyle / healthwellness / article / 30,97,606 / mental-health-and-working-home-what-comppanies-can-do-help

Teo, J. (2020). "Teleworkers feel more stressed than frontline workers exposed to Covid-19: Investigation." Accessed August 19, 2020.https://www.straitstimes.com/singapore/health/more-work-from-homers-feelstress-than-front-line-workers-singapore-survey-on

The World Bank Group. (2020)."Individuals using the Internet (\% of the population) - Cameroon data." April

24 ,

2021 https://data.worldbank.org/indicator/IT.NET.USER.ZS?locations=CM\&most recent value desc=true

India time. (2020). "Working from home causes $67 \%$ of Indians to suffer from sleep deprivation, study finds." Accessed April 14, 2020.https://timesofindia.indiatimes.com/life-style / relationships / work / work-fromhome-made-67-indian-sleep-deprived-ation-said-study / articleshow / 75126242.cms

Troup, C. and J. Rose.2012. "Work from Home: Do Formal or Informal Telework Agreements Offer Better Work-Family Outcomes?" Community and Family Work 15 (4): 471-486. doi:10.1080 / 13668803.2012.724220.

Virick, M., N. DaSilva, and K. Arrington. (2010). "Moderators of the curvilinear relationship between the extent of telework and job and life satisfaction: the role of outcome orientation and worker type." Human relations 63 (1): 137-154. Doi: 10.1177 / 0018726709349198.

International Labor Organization (2016) Global Difficulty Dialogue Forum and the benefits of teleworking for workers and employers in ICT sectors and financial services - Final Report Ilo 12 (26) 43.

World Health Organization (2020). "COVID-19 Global Forum for Research and Innovation on Public Health Emergencies of International Concern (PHEIC)." Accessed February 12, 2020. https: // www.who.int/publications/m/item/covid-19-public-health-emergency-of-international-con-cern- (pheic) global-research-and-innovation-forum

World Health Organization (2020). "Coronavirus Disease (COVID-19) Situation Report - 202." Accessed August 9, 2020. https://www.who.int/docs/default-source/coronaviruse/situation-reports / 2, 02,00,809covid-19-sitrep-202.pdf? sfvrsn = 2c7459f6_2 